\title{
HUBUNGAN ANTARA KUALITAS PRODUK DAN CITRA MEREK DENGAN KEPUTUSAN PEMBELIAN PADA PT. HYUNDAI MOBIL INDONESIA CABANG SERPONG-TANGERANG
}

\section{THE CORRELATION BETWEEN QUALITY OF PRODUCT AND BRAND IMAGE WITH PURCHASE DECISION IN PT. HYUNDAI MOBIL INDONESIA - SERPONG TANGERANG.}

\author{
Yulianingsih \\ Progam Management Studies Faculty of Economics, University of Djuanda Bogor \\ Email :yulianingsih.chandra@gmail.com
}

\begin{abstract}
The purpose of this study to determine the relationship between Product Quality and Brand Image with Purchase Decision. This study was conducted at PT.Hyundai Mobil Indonesia Serpong Tanggerang. The study population was 110 customers and the number of sample was 87 respondens by purposive sampling. Data collection for each variable studied using questionnaires with rating scale. The data analysis technique used correlation regression partial and multiple. The result show that there is relationship between product quality with purchase decision $\left(r_{y 1}=0.649\right)$, the relationship between Brand Image with Purchase Decision $\left(r_{y 2}=\right.$ $0.555)$, and relationship between product quality and brand image with purchase decision $\left(r_{y 12}=\right.$ 0.649). Based on the result, it can be conclude that purchase decision can be enhanced through Quality of Product and Brand Image either partially or together.
\end{abstract}

Keywords : product quality, brand image, purchasing decisions

\begin{abstract}
ABSTRAK
Penelitian bertujuan untuk menganalisis hubungan antara kualitas produk dan citra merek dengan keputusan pembelian. Penelitian dilaksanakan di PT. Hyundai Mobil Indonesia cabang SerpongTangerang pada tahun 2017. Populasi penelitian berjumlah 110 pelanggan dengan jumlah sampel sebanyak 87 pelanggan yang ditentukan secara purposive sampling. Pengumpulan data untuk setiap variabel yang dianalisis menggunakan angket dengan skala (rating scale). Teknik analisis menggunakan korelasi regresi parsial dan korelasi berganda. Hasil riset menunjukkan terdapat hubungan antara kualitas produk dengan keputusan pembelian $\left(\mathrm{r}_{\mathrm{y} 1}=0,649\right)$, terdapat hubungan antara citra merek dengan keputusan pembelian $\left(r_{y_{2}}=0,555\right)$ dan terdapat hubungan antara kualitas produk, citra merek dengan keputusan pembelian $\left(r_{\mathrm{y} 12}=0.649\right)$. Sehingga dapat disimpulkan keputusan pembelian dapat ditingkatkan melalui kualitas` produk dan citra merek baik secara parsial maupun bersama-sama.
\end{abstract}

Kata Kunci : kualitas produk, citra merek, keputusan pembelian. 


\section{PENDAHULUAN}

Industri otomotif saat ini berkembang pesat terutama di kota-kota besar, hal ini mengingat perubahan selera dan gaya hidup konsumen yang lebih mobile untuk mendukung kegiatan sehari-hari dengan mobilitas tinggi. Seiring dengan pesatnya perkembangan otomotif maka semakin ketat juga persaingan didunia otomotif. Setiap merek mobil saling bersaing dan menampilkan keunggulannya masing-masing. Persaingan merek bukan sekedar untuk membedakan dengan produk pesaing, tetapi sebagai salah satu factor untuk mencapai keunggulan kompetitif bagi produsen mobil.

PT. Hyundai Mobil Indonesia adalah penyuplai tunggal dari PT. Hyundai Indonesia Motor (HIM). PT HIM adalah Agen Tunggal Pemegang Merk (ATPM) dari kendaraan mobil asal Korea dengan merek Hyundai, yang didirikan pada tahun 1995. Eksistensi Hyundai telah di akui oleh pasar tanah air. Media massa memberikan banyak penghargaan pada beberapa mobil Hyundai di antaranya adalah menempatkan Hyundai i10 sebagai best city car, i20 sebagai best compact hatchback versi autobuid award 2009 dll. Dengan dukungan manajemen berbasis teknologi kualitas tinggi mendorong Hyundai menempati posisi ke-5 pada penghargaan word's most admire companies versi majalah fortune, dan adanya pengakuan dari lembaga penelitian internasional J.D Power yang menposisikan Hyundai berada pada peringkat ke empat besar (2009) dengan kategori kualitas mobil baru yang dimiliki konsumen selama 90 hari .

Berdasarkan data penjualan mobil secara nasional dalam 4 tahun terakhir ini, pada tahun 2015 penjualan mobil mengalami penurunan sedangkan tahun 2016 sedikit mengalami kenaikan (Sumber: Gaikindo.or.id), hal ini dapat terlihat pada grafik berikut:

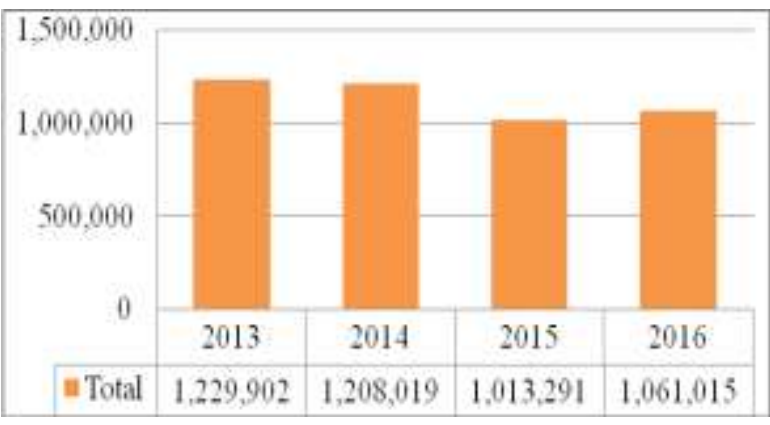

Gambar 1: Grafik Penjualan Mobil Tahun 2013 - Tahun 2016

\section{Sumber : Gaikindo}

Hal berbeda terjadi pada penjualan mobil Hyundai pada PT. HMI cabang SerpongTangerang. Selama 3 tahun terakhir, terjadi penurunan penjualan dari target yang sudah ditetapkan oleh pihak manajemen. Tahun 2014 target penjualan terealisasi hanya $78 \%$, pada tahun 2015 target penjualan terealisasi $65 \%$ dan pada tahun 2016 target penjualan terealisas $57 \%$ atau penjualan semakin turun dari tahun ketahun .

Berdasarkan hasil survey yang dilakukan oleh PT. Hyundai Mobil Indonesia pada tahun 2015 dalam ajang pameran Indonesia Internasional Motor Show ( IIMS), dimana respondennya adalah konsumen yang mengunjungi stand mobil Hyundai, diketahui beberapa faktor yang menyebabkan berkurangnya minat beli masyarakat terhadap mobil Hyundai adalah:

1. Masyarakat masih meragukan kualitas produk mobil asal Korea (Hyundai dan KIA ).

2. Masyarakat belum banyak mengenal merek mobil Hyundai beserta kelebihannya.

3. Kurangnya promosi yang dilakukan Hyundai melalui media massa baik cetak maupun elektronik.

4. Harga mobil Hyundai masih dianggap terlalu mahal dan tidak sebanding dengan kualitas. 
5. Harga jual mobil Hyundai menyusut jauh (tingkat kerugian yang tinggi)

6. Tidak diketahuinya Selling Point dari Hyundai oleh sebagian besar masyarakat, antara lain : jaminan unit beli kembali 3 tahun, jaminan mesin 3 tahun atau 100.000 KM ( Warranty 3 years or 100.000 KM ), jaminan pesanan suku cadang akan datang dalam waktu 2 hari atau gratis, layanan home service dll.

Berdasarkan data-data di atas terdapat permasalahan dalam keputusan pembelian salah satunya disebabkan oleh kualitas produk dan citra merek.

Kualitas produk merupakan kemampuan produk untuk memuaskan kebutuhan atau keinginan pelanggan (Cannon, et. al., 2008:286). Jika perusahaan ingin berkembang dan meraih keuntungan, maka perusahaan harus mengadopsi konsep kualitas. Ini menunjukkan bahwa kualitas mempunyai pengaruh terhadap konsumen.

Citra merek adalah kesan yang diperoleh sesuai dengan pengetahuan dan pemahaman seseorang tentang sesuatu (Alma, 2014:375). Citra merek positif dapat memberikan keunggulan bagi perusahaan di antaranya dapat menciptakan keunggulan bersaing. Produk yang mempunyai citra merek baik cenderung lebih mudah diterima konsumen. Citra merupakan keseluruhan persepsi terhadap produk atau merek yang dibentuk dari informasi dan pengalaman masa lalu terhadap produk atau merek itu (Sutisna, 2003:83).

Dalam melakukan strategi pemasaran mobil Hyundai, PT. HMI menggunakan beberapa strategi diantaranya kualitas produk dan citra merek. Setiap variabel akan saling berhubungan sehingga perusahaan dapat memilih variabel terbaik terhadap produk yang diperjualbelikan.

Adapun dasar pemilihan PT. HMI cabang Serpong-Tangerang sebagai objek penelitian karena pertimbangan perusahaan tersebut sebagai dealer dan juga bengkel resmi dari
PT. Hyundai Indonesia Motor (HIM) yang melakukan perawatan, penjualan serta perbaikan segala jenis mobil merek Hyundai serta memiliki lokasi strategis di tengah kota yaitu di Jl. Raya Serpong KM. 7 No.32, Kota Tangerang Selatan, Banten.

Tujuan riset ini yaitu :

1. Menganalisis hubungan kualitas produk dengan keputusan pembelian pada PT. Hyundai Mobil Indonesia.

2. Menganalisis hubungan citra merek dengan keputusan pembelian pada PT. Hyundai Mobil Indonesia.

3. Menganalisis hubungan kualitas produk dan citra merek secara bersama-sama dengan keputusan pembelian pada PT. Hyundai Mobil Indonesia.

\section{MATERI DAN METODE}

\section{Kualitas Produk}

Kualitas merupakan konsep esensial dalam menciptakan sebuah produk. Kualitas diawali dari kebutuhan pelanggan dan berakhir dengan persepsi dari pelanggan. Aaker (2010) berpendapat bahwa persepsi kualitas (Perceived quality) merupakan persepsi pelanggan terhadap totalitas kualitas atau keunggulan suatu produk atau layanan berkenaan dengan apa yang diharapkan oleh pelanggan. Menurut Kotler dan Armstrong (2008:266) kualitas produk adalah kombinasi dari daya tahan, keandalan, ketepatan, kemudahan dalam pemeliharaan serta atributatribut lainnya dari suatu produk dalam menjalankan fungsinya.

\section{Citra Merek}

Citra merek merupakan suatu kepercayaan dari konsumen terhadap suatu merek pada produk tertentu yang dapat diukur berdasarkan pendapat, kesan, respon dari audien sasaran dengan tujuan untuk melihat secara pasti apa yang ada didalam pikiran individu mengenai suatu objek dan bagaimana mereka memahami 
apa yang mereka sukai atau tidak dari objek tersebut. Biel (2009:90) mendefinisikan citra merek adalah sebagai citra tentang merek yang dianggap sebagai kelompok asosiasi yang menghubungkan pemikiran konsumen terhadap suatu nama merek. Sedangkan asosiasi adalah segala hal yang berhubungan dengan ingatan konsumen terhadap suatu merek.

\section{Keputusan Pembelian}

Setiap konsumen melakukan berbagai keputusan tentang pencarian, pembelian, penggunaan produk dan merek pada setiap periode tertentu. Menurut Kotler (2002:184), keputusan pembelian merupakan tindakan dari konsumen untuk membeli atau tidak terhadap produk perusahaan. Dari beragam faktor yang dapat mempengaruhi konsumen dalam melakukan pembelian suatu produk, konsumen cenderung akan mempertimbang kualitas, harga dan merek yang sudah dikenal di masyarakat.

\section{Penelitian Terdahulu}

Fauziah Ramadhani (2015) meneliti tentang Pengaruh kualitas, harga dan citra merek terhadap pengambilan keputusan pembelian LCGC Toyota Agya di wilayah Jabodetabek. Tujuan penelitiannya adalah untuk mengidentifikasi karakteristik responden Toyota Agya dan mengkaji pengaruh kualitas, harga, dan citra merek terhadap keputusan pembelian $L C G C$ Toyota Agya. Ria Maharani Ridhwan (2014) meneliti tentang Pengaruh Citra Merek dan Kualitas produk terhadap Pengambilan Keputusan Pembelian mobil Honda Jazz di Kota Malang. Hasil riset menunjukkan bahwa secara parsial citra merek dan kualitas produk mempengaruhi keputusan pembelian . Ryanto Hariandy Wangen dan Silvya L Mandey (2014) meneliti mengenai Analisis Citra Merek, Kualitas Produk dan Harga Pengaruhnya Terhadap Keputusan Pembelian Konsumen pada Mobil All New KIA Rio di
Kota Manado. Berdasarkan penelitian terdapat tiga faktor yang dapat mempengaruhi konsumen terkait keputusan pembelian yaitu citra merek, kualitas produk dan harga. Hasil penelitian menunjukkan nilai koefisien korelasi 0,858 yang artinya adalah citra merek, kualitas produk dan harga memiliki hubungan yang kuat terhadap keputusan pembelian sebesar $85,8 \%$.

\section{Kerangka Konseptual}

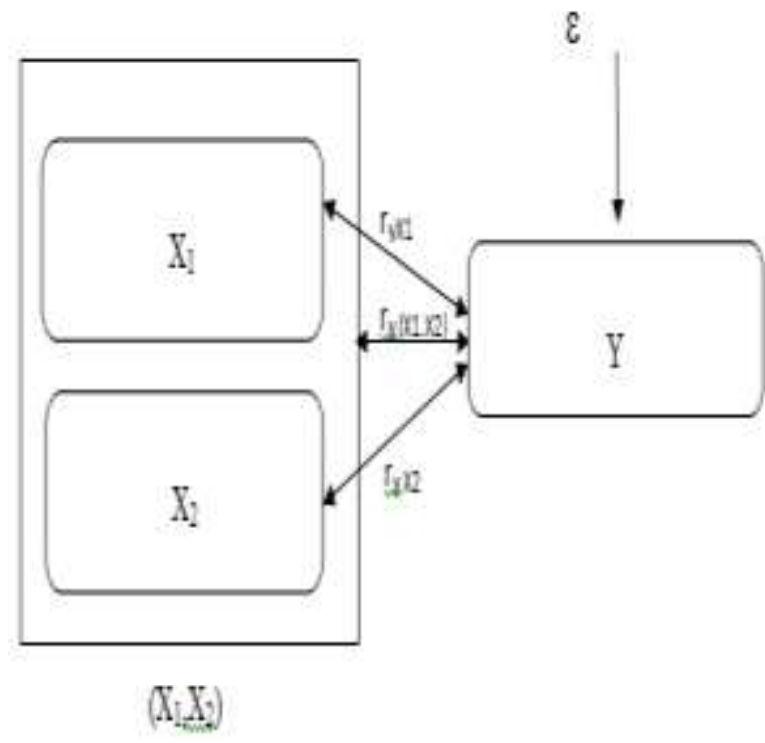

Gambar 2. Konstelasi Model Hubungan Antar Variabel

Keterangan gambar :

$\mathrm{X}_{1}$ : kualitas produk, $\mathrm{X}_{2}$ : citra merek, $\mathrm{X}_{1} \cdot \mathrm{X}_{2}$ : kualitas produk bersama-sama dengan citra merek, $\mathrm{Y}$ :Keputusan pembelian, $\mathrm{r}_{\mathrm{y} .1}$ : koefisien korelasi kualitas produk dengan keputusan pembelian, $r_{\mathrm{y} .2}$ : koefisien korelasi citra merek dengan keputusan pembelian, $\mathrm{r}_{\mathrm{y} \cdot 1.2}$ : koefisien korelasi kualitas produk dan citra merek secara bersama-samadengan keputusan pembelian, $\varepsilon$ : variabel lain yang tidak diteliti.

\section{Hipotesis}

Hipotesis yang diajukan dalam penelitian adalah: 
$\mathrm{H}_{1}$ : Terdapat hubungan positif antara kualitas produk dengan keputusan pembelian

$\mathrm{H}_{2}$ :Terdapat hubungan positif antara citra merek dengan keputusan pembelian.

$\mathrm{H}_{3}$ : Terdapat hubungan positif antara kualitas produk dan citra merek secara bersamasama dengan keputusan pembelian.

\section{Desain Penelitian}

Jenis penelitian bersifat kuantitatif yaitu merupakan jenis penelitian berdasarkan filsafat positivisme untuk meneliti populasi dan sampel tertentu. Analisis data bersifat kuantitatif/statistic bertujuan menguji hipotesis yang sudah ditetapkan sebelumnya (Sugiono 2010:13).

Penelitian menggunakan metode survey. Data dikumpulkan berdasarkan jawaban responden yang diajukan oleh peneliti melalui kuesioner. Daftar pertanyaan berisi persepsi dari responden mengenai kualitas produk, citra merek dan keputusan pembelian terhadap mobil Hyundai. Pengukuran mengenai kualitas produk, citra merek dan keputusan pembelian berdasarkan pada respon terhadap skala Likert. Para responden diberi pertanyaan bagaimana penilaian mereka terhadap kualitas produk, citra merek dan keputusan pembelian mereka terhadap mobil Hyundai, kemudian disusun skala dari 1 sampai 5 yaitu sangat setuju sampai dengan sangat tidak setuju. Lima alternatif jawaban yang digunakan adalah Sangat Setuju (SS), Setuju (S), Ragu-ragu (R), Tidak Setuju (TS) dan Sangat Tidak Setuju (STS). Penggunakan metode survey berdasarkan pertimbangan bahwa metode ini sangat ekonomis, cepat dan menjamin keleluasaan responden untuk menjawab dan memberikan informasiinformasi yang diperlukan.

\section{Populasi dan Sampel}

Populasi penelitian adalah pelanggan perorangan (bukan pelanggan perusahaan) yang membeli mobil Hyundai pada tahun 2016 sebanyak 110 pelanggan.Untuk mendapatkan jumlah sampel digunakan rumus Slovin dengan taraf kesalahan 5\% dan hasil perhitungan diperoleh sampel sebanyak 87 responden. Teknik pengambilan sampel menggunakan purposive sampling. (penentuan sampel dengan kriteria tertentu). Kriteria sampel yang ditentukan adalah pelanggan yang telah melakukan servis berkala pada bulan Januari 2016 sampai dengan Desember 2016 di bengkel resmi PT. HMI cabang Serpong.

\section{Definisi Operasional Variabel}

\section{Variabel Bebas /Variabel Independen}

\section{Kualitas Produk}

Kualitas produk dapat disintesiskan sebagai keunggulan produk berkaitan dengan kemampuannya untuk melaksanakan fungsinya. Dimensi kualitas produk dalam penelitian ini adalah
a) kinerja (performance),
b) ciri-ciri atau keunggulan tambahan (features),
c) kehandalan (reliability),
d) kesesuaian spesifikasi (conformance to specifications),
e) daya tahan (durability),
f) service ability,
g) estetika, dan
h) kualitas yang dipersepsikan.

\section{Citra Merek}

Citra merek disintesiskan sebagai persepsi dan keyakinan terhadap sebuah merek yang ada didalam ingatan konsumen. Dimensi citra merek dalam penelitian:

a) corporate image (citra pembuat).

b) recognition (tingkat dikenalnya suatu merek oleh konsumen)

c) reputation

d) affinity (emosional relationship yang timbul antara merek dengan konsumennya)

e) loyalty (kesetiaan terhadap merek) 
Variabel Terikat/Variabel Dependen

\section{Keputusan Pembelian}

Keputusan pembelian dapat disintesiskan sebagai seleksi terhadap dua pilihan alternative atau lebih mengenai preferensi atas merek-merek yang ada di dalam kumpulan pilihan dan memilih salah satu diantaranya. Dimensi Keputusan pembelian dalam penelitian adalah:

a) benefit association (manfaat produk yang akan dibeli dan menghubungkannya dengan karakteristik merek.

b) kebiasaan didalam membeli suatu produk.

c) prioritas dalam membeli.

d) melakukan pembelian ulang.

e) pembelian sendiri.

f) memberikan rekomendasi kepada pihak lain

g) bertindak karena keunggulan produk.

\section{Metode Analisis}

Analisis data merupakan metode yang menggambarkan sejauh mana suatu variabel memiliki pengaruh/hubungan terhadap variabel lain. Tujuannya adalah untuk menginterprestasikan serta menarik suatu kesimpulan dari sejumlah data yang terkumpul sehingga dapat dijadikan dasar dalam pengambil keputusan. Metode analisis yang digunakan adalah :

1. Uji Asumsi Klasik.

Uji asumsi dilakukan untuk memperoleh hasil analisa regresi yang valid. Uji asumsi yang digunakan adalah :

a) Uji Normalitas .

Uji normalitas dilakukan untuk mengetahui normal atau tidaknya suatu distribusi data. Uji normalitas menggunakan teknik Kolmogorov Smirnov . Data berdistribusi normal, bila nilai sig. (signifikansi) > 0,05 sebaliknya bila nilai sig. (signifikansi < 0.05 maka dikatakan berdistribusi tidak normal.

b) Uji Homogenitas
Uji homogenitas adalah uji mengenai sama tidaknya variasi-variasi dua buah distribusi atau lebih. Uji homogenitas terhadap data $X_{1}, X_{2}$ dan $\mathrm{Y}$ menggunakan teknik Lavene.

c) Uji Linieritas

Uji linearitas dilakukan untuk mengetahui linear tidaknya hubungan dari variabel-variabel penelitian. Uji linearitas digunakan untuk mengkonfirmasi apakah sifat linear dua variabel yang diidentifikasikan secara teori sesuai atau tidak dengan hasil observasi yang ada.

2. Analisis regresi berganda

1) Analisis Koefisien Determinasi (Adjusted $R^{2}$ )

Koefisien determinasi yaitu ukuran untuk kesesuaian atau ketepatan hubungan variabel independen dengan variabel dependen dalam suatu persamaan regresi. Koefisien Determinasi $\left(\mathrm{r}^{2}\right)$ pada intinya mengukur seberapa besar sumbangan variabel independen terhadap variabel dependen.

2) Pengujian Hipotesis

a) Uji F

Analisis ini dilakukan untuk menguji hipotesis yaitu untuk mengetahui signifikansi hubungan variabel kualitas produk dan citra merek secara simultan (bersamasama) dengan keputusan pembelian. Menurut Riduwan \& Sunarto (2011:91), kaidah pengujian signifikansi yang ditentukan adalah: jika $F$ hitung $>\mathrm{F}_{\text {tabel }}$, maka tolak $\mathrm{H}_{0}$ dan $\mathrm{H}_{1}$ diterima dan jika $\mathrm{F}$ hitung $<\mathrm{F}_{\text {tabel }}$, maka terima $\mathrm{H}_{0}$ dan $\mathrm{H}_{1}$ ditolak.

b) Uji - $t$

Analisis dilakukan untuk menguji hipotesis yaitu untuk mengetahui signifikansi hubungan 
antara variabel bebas secara sendiri-sendiri terhadap variabel terikat.Menurut Riduwan \& Sunarto (2011:91), kaidah pengujian signifikansi ditentukan sebagai berikut :Jika $t_{\text {hitung }}>t_{\text {tabel }}$, maka tolak $\mathrm{H}_{0}$ dan $\mathrm{H}_{1}$ diterima dan bila $\mathrm{t}_{\text {hitung }}<\mathrm{t}$ tabel, maka terima $\mathrm{H}_{0}$ dan $\mathrm{H}_{1}$ ditolak.

3) Uji Validitas.

Pengujian validitas dilakukan untuk menguji pertanyaan dari intrumen kuesioner apakah mampu mengungkapkan sesuatu yang ingin diukur. Tingkat validitas diukur dengan mengkomparasikan nilai $r_{\text {hitung }}$ dengan $r_{\text {tabel }}$ berdasarkan ketentuan degree of freedom $(\mathrm{df})=\mathrm{n}-\mathrm{k}$, dimana $\mathrm{n}$ merupakan jumlah sampel dan $\mathrm{k}$ adalah jumlah dari variabel bebas. Kriteria uji validitas yaitu : $\mathrm{r}_{\text {hitung }}>$ $\mathrm{r}_{\text {tabel }}$,maka pertanyaan tersebut valid, dan bila $r_{\text {hitung }}<r_{\text {tabel }}$, maka pertanyaan tersebut tidak valid.

4) Uji Reliabilitas

Kuesioner dikatakan reliabel atau handal bila jawaban seseorang terhadap pernyataan adalah konsisten atau stabil dari waktu kewaktu. Alat untuk mengukur konsistensi instrumen menggunakan rumus Cronbach's Alpha dengan criteria pengujian : pernyataan dikatakan reliable bila nilai Cronbach's Alpha > 0,6 dan dikatakan tidak reliable bila nilai Cronbach's Alpha $\leq 0,6$.

\section{Analisis Antar Dimensi}

Analisis antara dimensi dilakukan dengan menggunakan rumus korelasi Product Moment Pearson. Product Moment Pearson merupakan uji statistik untuk menguji hipotesis asosiatif (uji hubungan) dua variabel dimana datanya berskala atau rasio. Fungsinya adalah menguji kemampuan generalisai (signifikasi) hasil penelitian.
Matrik korelasi dimensi antar variabel dijelaskan pada tabel berikut :

Tabel 1. Uji Analisis Dimensi

\begin{tabular}{|c|c|c|c|c|c|c|c|c|}
\hline \multirow[b]{2}{*}{ Variabel } & \multirow[b]{2}{*}{ Indikator } & \multicolumn{7}{|c|}{$r_{y x}$} \\
\hline & & $\mathrm{y}_{1}$ & $\mathrm{y}_{2}$ & $\mathrm{y}_{3}$ & $y_{4}$ & $\mathrm{y}_{5}$ & $\mathrm{y}_{6}$ & $y_{7}$ \\
\hline \multirow{8}{*}{$\mathrm{X}_{1}$} & $\mathrm{x}_{1.1}$ & $\mathrm{ry}_{1} \mathrm{x}_{1 \cdot 1}$ & $\mathrm{ry}_{2} \mathrm{x}_{1 \cdot 1}$ & $\mathrm{ry}_{3} \mathrm{x}_{1 \cdot 1}$ & $\mathrm{ry}_{4} \mathrm{x}_{1 \cdot 1}$ & $\mathrm{ry}_{5} \mathrm{x}_{1 \cdot 1}$ & $\mathrm{ry}_{6} \mathrm{x}_{1 \cdot 1}$ & $\mathrm{ry}_{7} \mathrm{x}_{1 \cdot 1}$ \\
\hline & $\mathrm{x}_{1 \cdot 2}$ & $\mathrm{ry}_{1} \mathrm{x}_{1.2}$ & $\mathrm{ry}_{2} \mathrm{x}_{12 .}$ & $\mathrm{ry}_{3} \mathrm{x}_{1.2}$ & $\mathrm{ry}_{4} \mathrm{x}_{1.2}$ & $\mathrm{ry}_{5} \mathrm{x}_{1.2}$ & $\mathrm{ry}_{6} \mathrm{x}_{1.2}$ & $\mathrm{ry}_{7} \mathrm{x}_{1.2}$ \\
\hline & $\mathrm{x}_{1.3}$ & $\mathrm{ry}_{1} \mathrm{x}_{1 \cdot 3}$ & $\mathrm{ry}_{2} \mathrm{x}_{1 \cdot 3}$ & $\mathrm{ry}_{3} \mathrm{x}_{1.3}$ & $\mathrm{ry}_{4} \mathrm{x}_{1.3}$ & $\mathrm{ry}_{5} \mathrm{x}_{1.3}$ & $\mathrm{ry}_{6} \mathrm{x}_{1.3}$ & $\mathrm{ry}_{7} \mathrm{x}_{1.3}$ \\
\hline & $\mathrm{x}_{1.4}$ & $\mathrm{ry}_{1} \mathrm{x}_{14}$ & $\mathrm{ry}_{2} \mathrm{x}_{14}$ & $\mathrm{ry}_{3} \mathrm{x}_{14}$ & $\mathrm{ry}_{4} \mathrm{x}_{14}$ & $\mathrm{ry}_{5} \mathrm{x}_{14}$ & $\mathrm{ry}_{6} \mathrm{x}_{14}$ & $\mathrm{ry}_{7} \mathrm{x}_{14}$ \\
\hline & $\mathrm{x}_{1.5}$ & $\mathrm{ry}_{1} \mathrm{x}_{1.5}$ & $\mathrm{ry}_{2} \mathrm{x}_{1.5}$ & $\mathrm{ry}_{3} \mathrm{x}_{1.5}$ & $\mathrm{ry}_{4} \mathrm{x}_{1.5}$ & $\mathrm{ry}_{5} \mathrm{x}_{1.5}$ & $\mathrm{ry}_{6} \mathrm{x}_{1.5}$ & $\mathrm{ry}_{7} \mathrm{x}_{1.5}$ \\
\hline & $x_{1.6}$ & $\mathrm{ry}_{1} \mathrm{x}_{16}$ & $\mathrm{ry}_{2} \mathrm{x}_{16}$ & $\mathrm{ry}_{3} \mathrm{x}_{16}$ & $\mathrm{ry}_{4} \mathrm{x}_{16}$ & $\mathrm{ry}_{5} \mathrm{x}_{16}$ & $\mathrm{ry}_{6} \mathrm{x}_{16}$ & $\mathrm{ry}_{7} \mathrm{x}_{16}$ \\
\hline & $\mathrm{x}_{1.7}$ & $\mathrm{ry}_{1} \mathrm{x}_{1 \cdot 7}$ & $\mathrm{ry}_{2} \mathrm{x}_{1 \cdot 7}$ & $\mathrm{ry}_{3} \mathrm{x}_{1 \cdot 7}$ & $\mathrm{ry}_{4} \mathrm{x}_{1 \cdot ?}$ & $\mathrm{ry}_{5} \mathrm{x}_{1 \cdot ?}$ & $\mathrm{ry}_{6} \mathrm{x}_{1.7}$ & $\mathrm{ry}_{7} \mathrm{x}_{1.7}$ \\
\hline & $\mathrm{x}_{1.8}$ & $\mathrm{ry}_{1} \mathrm{x}_{1.8}$ & $\mathrm{ry}_{2} \mathrm{x}_{1.8}$ & $\mathrm{ry}_{3} \mathrm{x}_{18}$ & $\mathrm{ry}_{4} \mathrm{x}_{1.8}$ & $\mathrm{ry}_{5} \mathrm{x}_{1.8}$ & $\mathrm{ry}_{6} \mathrm{x}_{1.8}$ & $\mathrm{ry}_{7} \mathrm{x}_{1.8}$ \\
\hline \multirow{5}{*}{$\mathrm{X}_{2}$} & $\mathrm{x}_{2 \cdot 1}$ & $\mathrm{ry}_{1} \mathrm{x}_{2 \cdot 1}$ & $\mathrm{ry}_{2} \mathrm{x}_{2 \cdot 1}$ & $\mathrm{ry}_{3} \mathrm{x}_{2 \cdot 1}$ & $\mathrm{ry}_{4} \mathrm{x}_{21}$ & $\mathrm{ry}_{5} \mathrm{x}_{21}$ & $\mathrm{ry}_{5} \mathrm{x}_{21}$ & $\mathrm{ry}_{5} \mathrm{x}_{21}$ \\
\hline & $\mathrm{x}_{2 \cdot 2}$ & $\mathrm{ry}_{1} \mathrm{x}_{2 \cdot 2}$ & $\mathrm{ry}_{2} \mathrm{x}_{2.2}$ & $\mathrm{ry}_{3} \mathrm{x}_{2.2}$ & $\mathrm{ry}_{4} \mathrm{x}_{2.2}$ & $\mathrm{ry}_{5} \mathrm{x}_{2.2}$ & $\mathrm{ry}_{5} \mathrm{x}_{2.2}$ & $\mathrm{ry}_{5} \mathrm{x}_{2.2}$ \\
\hline & $x_{2 \cdot 3}$ & $\mathrm{ry}_{1} \mathrm{x}_{2.3}$ & $\mathrm{ry}_{2} \mathrm{x}_{2.3}$ & $\mathrm{ry}_{3} \mathrm{x}_{2.3}$ & $\mathrm{ry}_{4} \mathrm{x}_{2.3}$ & $\mathrm{ry}_{5} \mathrm{x}_{2.3}$ & $\mathrm{ry}_{5} \mathrm{x}_{2.3}$ & $\mathrm{ry}_{5} \mathrm{x}_{2.3}$ \\
\hline & $\mathrm{x}_{2.4}$ & $\mathrm{ry}_{1} \mathrm{x}_{24}$ & $\mathrm{ry}_{2} \mathrm{x}_{24}$ & $\mathrm{ry}_{3} \mathrm{x}_{24}$ & $\mathrm{ry}_{4} \mathrm{x}_{24}$ & $\mathrm{ry}_{5} \mathrm{x}_{24}$ & $\mathrm{ry}_{5} \mathrm{x}_{24}$ & $\mathrm{ry}_{5} \mathrm{x}_{24}$ \\
\hline & $\mathrm{X}_{2.5}$ & $\mathrm{ry}_{1} \mathrm{x}_{2.5}$ & $\mathrm{ry}_{2} \mathrm{x}_{2.5}$ & $\mathrm{ry}_{3} \mathrm{x}_{2.5}$ & $\mathrm{ry}_{4} \mathrm{x}_{2.5}$ & $\mathrm{ry}_{5} \mathrm{x}_{2.5}$ & $\mathrm{ry}_{5} \mathrm{x}_{2.5}$ & $\mathrm{ry}_{5} \mathrm{x}_{2.5}$ \\
\hline
\end{tabular}

Keterangan:

$\mathbf{Y}=$ Keputusan Pembelian; $\mathrm{Y}_{1}=$ Benefit Association; $\mathrm{Y}_{2}=$ Kebiasaan didalam membeli produk; $\mathrm{Y}_{3}=$ Prioritas dalam membeli $; \mathrm{Y}_{4}=$ Melakukan pembelian ulang; $\mathrm{Y}_{5}=$ Pembelian Sendiri; $\mathrm{Y}_{6}=$ Memberikan rekomendasi kepada pihak lain; $\mathrm{Y}_{7}=$ Bertindak karena keunggulan produk; $\mathbf{X}_{\mathbf{1}}=$ Kualitas Produk; $\mathrm{X}_{1.1}=\quad$ Kinerja (Performance); $\quad \mathrm{X}_{1.2}=$ Keistimewaan Tambahan (Features); $\mathrm{X}_{1.3}=$ Kehandalan (Reliability); $\mathrm{X}_{1.4}=$ Kesesuaian spesifikasi (Conformance); $\mathrm{X}_{1.5}=$ Daya Tahan (Durability); $\mathrm{X}_{1.6}=$ Kemampuan Pelayanan (Service ability); $\mathrm{X}_{1.7}=$ Keindahan (Estetika); $\mathrm{X}_{1.8}=$ Kualitas yang dipersepsikan (Perceived quality); $\mathbf{X}_{2}=$ Citra Merek; $\mathrm{X}_{2.1}=$ Corporate image; $\mathrm{X}_{2.2}=$ Recognation; $\mathrm{X}_{2.3}=$ Reputation; $\mathrm{X}_{2.4}=$ Affinity' $\mathrm{X}_{2.5}=$ Loyalty.

Tingkat kekuatan hubungan antar dimensi tersebut dapat diinterpertasikan seperti terlihat pada tabel berikut : 


\section{Tabel 2. Koefisien Korelasi dan Tingkat Kekuatan Hubungan}

\begin{tabular}{|c|c|}
\hline Koefisien Korelasi & Tingkat Kekuatan Hubungan \\
\hline $0,000-0,199$ & Sangat Lemah \\
\hline $0,200-0,399$ & Lemah \\
\hline $0,400-0,599$ & Sedang \\
\hline $0,600-0,799$ & Kuat \\
\hline $0,80-1,000$ & Sangat Kuat \\
\hline
\end{tabular}

Sumber : Sugiono (2010:250)

\section{HASIL DAN PEMBAHASAN}

\section{Karakteristik Responden}

Penelitian ini dilaksanakan di PT. Hyundai Mobil Indonesia cabang Serpong Tangerang dengan karakteristik responden adalah 63,2 \% berdomisili di kota Tangerang, 42,5\% berusia 36-45 tahun, 66,7\% berpenghasilan diatas 25 juta, 40,2 \% bekerja sebagai wiraswasta, 55,2 $\%$ memilih membeli mobil jenis SUV, 86,2 \% memilih membeli mobil dengan cara kredit, $59,8 \%$ responden memiliki 2 mobil, 87,4\% responden dalam penelitian merasa kepuasan dalam pembelian, 56,3\% responden kadang kadang membutuhkan saran dalam pembelian, $73,6 \%$ tidak ragu dalam melakukan pembelian, 65,5 \% responden menyatakan kualitas produk sebagai faktor utama dalam pembelian, 29,9 \% menyatakan "tidak" untuk mempertimbangkan merek mobil lain, 86,2 \% responden dalam penelitian akan rekomendasi kepada pihak lain agar membeli mobil merek Hyundai.

\section{Hasil Uji Asumsi Klasik}

\section{Uji Normalitas}

Uji normalitas menggunakan metode One Sample Kolmogorov-Smirnov dengan bantuan SPSS 20, taraf signifikansi $\alpha=0,05$, dengan hipotesis: $\mathrm{H}_{0}$ : sampel tidak berasal dari populasi berdistribusi normal, $\mathrm{H}_{1}$ : sampel berasal dari populasi berdistribusi normal. Kriteria pengujian : Bila nilai signifikansi < 0,05, maka $\mathrm{H}_{0}$ ditolak dan bila nilai signifikansi $>0,05$ maka $\mathrm{H}_{1}$ diterima. Berdasarkan hasil analisa data uji normalitas terhadap kualitas produk dengan metode OneSample Kolmogorov-Smirnov diperoleh hasil tes derajat yaitu signifikan $0,33>0,05$, citra merek 0,21 >0,05, dan keputusan pembelian $0,27>0,05$ dengan demikian skor pada variabel kualitas produk, citra merek dan keputusan pembelian berdistribusi normal.

\section{Uji Homogenitas}

Uji homogenitas dilakukan untuk mengetahui apakah varians populasi bersifat homogen. dengan hipotesis sebagai berikut : $\mathrm{H}_{0}$ : sampel tidak bersumber dari populasi yang homogen, $\mathrm{H}_{1}$ : sampel bersumber dari populasi yang homogen. Dengan kriteria pengujian adalah jika nilai signifikan $<0,05$ maka $\mathrm{H}_{0}$ ditolak dan jika nilai signifikan > 0,05 maka $\mathrm{H}_{1}$ diterima. Berdasarkan hasil perhitungan diperoleh nilai signifikansi kualitas produk $\left(\mathrm{X}_{1}\right)$ dengan keputusan pembelian (Y) adalah sebesar 0,038. Persyaratan data homogen adalah $>0,05$. Nilai signifikan $0,038>0,05$, nilai signifikansi citra merek $\left(\mathrm{X}_{2}\right)$ dengan keputusan pembelian (Y) adalah sebesar 0,089, nilai signifikan 0,089 > 0,05, dengan demikian $\mathrm{H}_{1}$ di terima, artinya data keputusan pembelian (Y) dengan kualitas produk $\left(\mathrm{X}_{1}\right)$ dan citra merek $\left(\mathrm{X}_{2}\right)$ berasal dari populasi varian yang sama (homogen).

\section{Uji Linieritas}

Uji linieritas dilakukan untuk mengetahui apakah persamaan regresi yang diperoleh linier atau tidak. Uji tersebut digunakan sebagai prasyarat untuk analisa korelasi atau regresi linier. Pengujian pada SPSS versi 20 menggunakan Test of Liniearity dengan kriteria penilaian linearity sig $<0,05$. Perumusan hipotesis statistik adalah : $\mathrm{H}_{0}$ : data tidak linier., $\mathrm{H}_{\mathrm{a}}$ : data linier. Berdasarkan hasil analisa data uji linieritas variabel kualitas produk $\left(\mathrm{X}_{1}\right)$ dan citra merek $\left(\mathrm{X}_{2}\right)$ dengan keputusan pembelian $(\mathrm{Y})$ diperoleh hasil sig. $=$ $0,000<0,05$ berarti $\mathrm{H}_{0}$ ditolak dan $\mathrm{H}_{\mathrm{a}}$ 
diterima, artinya persamaan regresi antara variabel kualitas produk dengan keputusan pembelian adalah linier.

\section{Hubungan Kualitas Produk Dengan Keputusan Pembelian}

Tabel 3. Signifikan Korelasi Variabel $X_{1}$

\begin{tabular}{|c|c|c|c|}
\hline & & $\begin{array}{l}\text { Keputusan } \\
\text { Pembelian }\end{array}$ & Kuslitas Produk \\
\hline \multirow[t]{3}{*}{ Keputusan Penbelian } & Pearson Correläion & 1 & $649^{2}$ \\
\hline & Sig (2taled) & & 000 \\
\hline & $\mathrm{N}$ & 87 & 87 \\
\hline \multirow[t]{3}{*}{ Kualitas Produk } & Pearson Correlation & $549^{\circ}$ & 1 \\
\hline & Sig (2-taled) &, 000 & \\
\hline & N & 87 & 87 \\
\hline
\end{tabular}

Sesuai dengan hipotesis penelitian maka hubungan kualitas produk $\left(\mathrm{X}_{1}\right)$ dengan keputusan pembelian (Y) menggunakan teknik korelasi Pearson product moment diperoleh koefisien korelasi $r_{\mathrm{y} .1}=0,649$. Berdasar hasil tersebut maka korelasi 0,649 termasuk kategori hubungan kuat.

Kontribusi koefisien determinasi kualitas produk $\left(\mathrm{X}_{1}\right)$ dengan keputusan pembelian (Y) dihitung berdasarkan koefisien korelasi $r_{\mathrm{y} .1}=$ 0,649 dijadikan koefisen determinasi yaitu $r^{2}=$ $\left(\mathrm{r}_{\mathrm{y} .1}\right)^{2}=(0,649)^{2}=0,421$ berarti variabel kualitas produk $\left(\mathrm{X}_{1}\right)$ memberikan kontribusi terhadap keputusan pembelian sebesar 42,1\% dan 57,9\% karena faktor lain.

Hubungan keduanya signifikan karena Sig $=0,000$. Nilai tersebut identik dengan $\rho$ value, dimana nilai $\rho$-value $<0,05$. Dengan demikian $\mathrm{H}_{0}$ ditolak dan $\mathrm{H}_{1}$ diterima berarti terdapat hubungan positif yang sedang dan signifikan antara kualitas produk $\left(\mathrm{X}_{1}\right)$ dengan keputusan pembelian (Y).

Untuk mengetahui hipotesis terdapat hubungan positif antara variabel $\mathrm{X}_{1}$ dan $\mathrm{Y}$ diperlukan uji signifikan korelasi yaitu dengan uji-t. Kriteria pengujian signifikan jika $t_{\text {hitung }}>$ $\mathrm{t}_{\text {tabel}}$. Dari hasil perhitungan menggunakan SPSS 20 diperoleh hasil adalah :
Tabel 4. Nilai $t$ Terhadap Variabel $X_{1}$ dan Y

Coefficients $^{\mathrm{a}}$

\begin{tabular}{|c|c|c|c|c|c|}
\hline \multirow[b]{2}{*}{ Model } & \multicolumn{2}{|c|}{ Unstandardiced Coefficients } & \multirow{2}{*}{$\begin{array}{c}\begin{array}{c}\text { Standardized } \\
\text { Coefficients }\end{array} \\
\text { Beta } \\
\end{array}$} & \multirow[b]{2}{*}{$t$} & \multirow[b]{2}{*}{ Sig. } \\
\hline & $\mathrm{B}$ & Std. Error & & & \\
\hline 1 (Constant) & 49,605 & 12261 & & 4,046 & .000 \\
\hline Kualitas Produk & 676 & .086 & .649 & 7,862 &, 000 \\
\hline
\end{tabular}

Dari tabel diatas diperoleh $t_{\text {hitung }}=7,862$. $\mathrm{t}_{\text {tabel }}$ (dengan tingkat sig $=0,05$ dan $\mathrm{n}-1=87$ $1=86$ ) ditentukan sebesar 1,988, sehingga nilai $7,862>1,988$ yang berarti kualitas produk $\left(\mathrm{X}_{1}\right)$ memiliki hubungan signifikan dengan keputusan pembelian (Y).

Berdasarkan hasil regresi linier sederhana diperoleh nilai koefisien regresi $b$ adalah 0,676 dan nilai konstanta a sebesar 49,605. Dengan demikian analisis regresi linier sederhana variabel kualitas produk dengan keputusan pembelian menghasilkan persamaan garis yaitu

$$
\hat{\mathrm{Y}}=49,605+0,676 \mathrm{X}_{1} \text {. }
$$

Persamaan di atas menggambarkan nilai konstanta (a) sebesar 49,605, yaitu menunjukkan bahwa bila kualitas produk konstan atau $\mathrm{X}_{1}=0$, maka keputusan pembelian sebesar 49,605. Koefisien beta $\left(b_{1}\right)$ sebesar 0,676 menunjukkan bahwa apabila kualitas produk ditingkatkan 1 poin maka akan meningkatkan keputusan pembelian sebesar 0,676 .

\section{Hubungan Citra Merek Dengan Keputusan Pembelian}

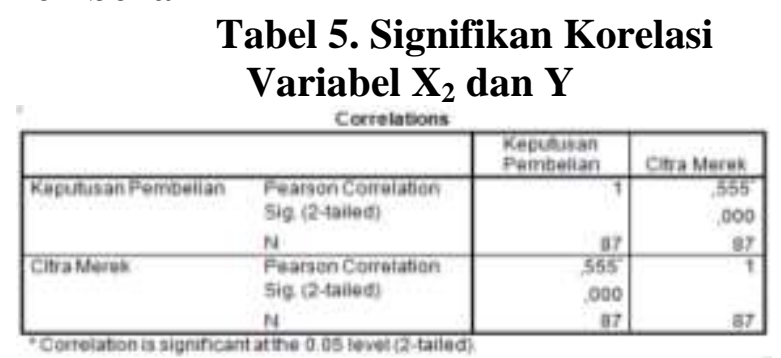

Sesuai dengan hipotesis penelitian maka korelasi citra merek $\left(\mathrm{X}_{2}\right)$ terhadap keputusan pembelian (Y) dengan teknik korelasi Pearson Product Moment diperoleh koefisien korelasi 
$\mathrm{r}_{\mathrm{y} .2}=0555$. Hasil tersebut termasuk kategori hubungan sedang.

Kontribusi koefisien determinasi antara citra merek $\left(\mathrm{X}_{2}\right)$ dengan keputusan pembelian (Y) dihitung berdasarkan koefisien korelasi $\mathrm{r}_{\mathrm{y} .2}=0,555$ dijadikan koefisen determinasi yaitu $r^{2}=\left(r_{y .2}\right)^{2}=(0,555)^{2}=0,308$ berarti variabel citra merek $\left(\mathrm{X}_{2}\right)$ memberikan kontribusi pada keputusan pembelian sebesar $30,8 \%$.

Hubungan keduanya signifikan karena Sig $=0,000$. Nilai tersebut identik dengan $\rho$ value, di mana nilai $\rho$ - value $<0,05$. Dengan demikian $\mathrm{H}_{0}$ ditolak dan $\mathrm{H}_{1}$ diterima berarti terdapat hubungan positif yang sedang dan signifikan antara citra merek $\left(\mathrm{X}_{2}\right)$ terhadap keputusan pembelian (Y).

Untuk mengetahui hipotesis terdapat hubungan positif antara variabel $\mathrm{X}_{2}$ dan $\mathrm{Y}$ diperlukan uji signifikan korelasi yaitu dengan uji-t. Kriteria pengujian signifikan jika $t_{\text {hitung }}>$ $\mathrm{t}$ tabel. Dari hasil perhitungan diperoleh hasil adalah :

\section{Tabel 6. Perhitungan Nilai t Terhadap} Variabel $X_{2}$ dan $Y$

\begin{tabular}{|c|c|c|c|c|c|c|}
\hline \multicolumn{7}{|c|}{ Coefficients $^{\mathrm{I}}$} \\
\hline & \multirow[b]{2}{*}{ Model } & \multicolumn{2}{|c|}{ Unstandardiced Coefficients } & $\begin{array}{l}\text { Standardiced } \\
\text { Coefficients }\end{array}$ & \multirow[b]{2}{*}{$T$} & \multirow[b]{2}{*}{ Sig. } \\
\hline & & B & Std. Ertor & Bete & & \\
\hline 1 & (Constart') & 71,325 & 12,133 & & 5,879 & 000 \\
\hline & Ctra Merek & 540 & $.08 B$ & 555 & 6,152 & 000 \\
\hline
\end{tabular}

Dari tabel di atas diperoleh $\mathrm{t}_{\text {hitung }}=6,152$, $\mathrm{t}_{\text {tabel }}$ (dengan tingkat sig $=0,05$ dan $\mathrm{n}-1=87$ $1=86$ ) ditentukan sebesar 1,988 ,sehingga nilai $6,152>1,988$ yang berarti variabel citra merek $\left(\mathrm{X}_{2}\right)$ memiliki korelasi signifikan dengan keputusan pembelian (Y).

Berdasarkan hasil dari analisis regresi linier sederhana diperoleh nilai koefisien regresi $b$ adalah 0,540 dan nilai konstanta a sebesar 71,325. Dengan demikian analisis regresi linier sederhana antara variabel citra merek dengan variabel keputusan pembelian menghasilkan persamaan garis yaitu : $\hat{\mathrm{Y}}=71,325+0,540 \mathrm{X}_{2}$.
Persamaan di atas menggambarkan nilai konstanta (a) sebesar 71,325, yaitu menunjukkan bahwa jika citra merek konstan atau $\mathrm{X}_{2}=0$, maka keputusan pembelian sebesar 71,325. Koefisien beta $\left(b_{2}\right)$ sebesar 0,540 menunjukkan bahwa apabila citra merek ditingkatkan 1 poin maka keputusan pembelian akan meningkat sebesar 0,540.

Hubungan antara Kualitas Produk $\left(X_{1}\right)$ dan Citra merek $\left(\mathbf{X}_{2}\right)$ Secara Bersamasama dengan Keputusan Pembelian (Y)

Tabel 7. Uji Signifikansi Korelasi Variabel $X_{1}$ dan $X_{2}$ secara bersamasama Dengan $Y$

Model Summary

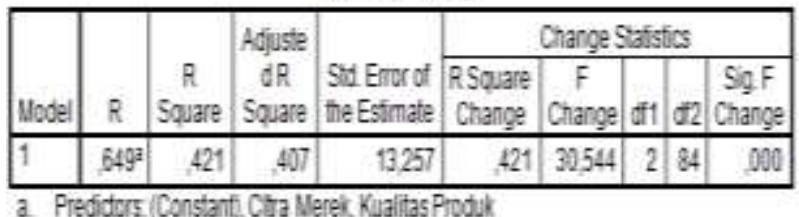

Sesuai dengan hipotesis penelitian maka korelasi kualitas produk $\left(\mathrm{X}_{1}\right)$ dan citra merek $\left(\mathrm{X}_{2}\right)$ secara bersama-sama terhadap keputusan pembelian (Y) dengan teknik korelasi berganda diperoleh koefisien korelasi $\mathrm{r}_{\mathrm{y} .1 .2}=$ 0,649, maka masuk kedalam kategori hubungan kuat.

Kontribusi koefisien determinasi kualitas produk $\left(\mathrm{X}_{1}\right)$ dan citra merek $\left(\mathrm{X}_{2}\right)$ secara bersama-sama dengan keputusan pembelian (Y) dihitung berdasarkan koefisien korelasi $r_{\mathrm{y} .1 .2}=0,649$ dijadikan koefisien determinasi yaitu $\mathrm{r}^{2}=\left(\mathrm{r}_{\mathrm{y} .1 .2}\right)^{2}=(0,649)^{2}=0,421$ artinya kualitas produk $\left(\mathrm{X}_{1}\right)$ dan citra merek $\left(\mathrm{X}_{2}\right)$ secara bersama-sama memberikan kontribusi terhadap keputusan pembelian sebesar $42,1 \%$ sisanya karena faktor lain.. Hubungan kedua variabel tersebut signifikan karena Sig $F$ Change $=0,000$. Nilai tersebut identik dengan $\rho$ - value, di mana nilai $\rho$ - value < 0,05. Dengan demikian, $\mathrm{H}_{0}$ ditolak dan $\mathrm{H}_{1}$ diterima berarti terdapat hubungan positif yang kuat dan signifikan antara kualitas 
produk $\left(\mathrm{X}_{1}\right)$ dan citra merek $\left(\mathrm{X}_{2}\right)$ secara bersama-sama dengan keputusan pembelian (Y).

Untuk mengetahui hipotesis terdapat hubungan positif variabel $\mathrm{X}_{1}$ dan $\mathrm{X}_{2}$ secara bersama-sama dengan $\mathrm{Y}$ diperlukan uji signifikan korelasi yaitu dengan uji $F$. Kriteria pengujian signifikan jika $\mathrm{F}$ hitung lebih besar dari $\mathrm{F}$ tabel.

\section{Tabel 8. Uji F}

ANONA

\begin{tabular}{|c|c|c|c|c|c|c|}
\hline Made & & Sun of Squares & Df & Mean Square & $F$ & Sig. \\
\hline \multirow[t]{3}{*}{1} & Regression & 10736.582 & 2 & 5368291 & 30544 & 00 \\
\hline & Residjal & 14763372 & 84 & 175754 & & \\
\hline & Total & 25499,954 & 86 & & & \\
\hline
\end{tabular}

a. DependentVariable Kenutusan Pentbelian

b. Predidurs: (Constart, Ctra Merek, Kualias Produ:

Dari tabel di atas diperoleh $\mathrm{F}$ hitung $=$ 30,544. Nilai $F$ tabel 1,181. Sehingga nilai $30,544>1,181$ yang berarti kualitas produk $\left(\mathrm{X}_{1}\right)$ dan citra merek $\left(\mathrm{X}_{2}\right)$ secara bersamasama memiliki korelasi signifikan dengan keputusan pembelian (Y).

Hubungan fungsional kualitas produk $\left(\mathrm{X}_{1}\right)$ dan citra merek $\left(\mathrm{X}_{2}\right)$ secara bersama-sama dengan keputusan pembelian (Y) dihitung menggunakan teknik analisas regeresi berganda seperti pada tabel di bawah ini:

Tabel 9. Hubungan Fungsional $X_{1}$ dan

$X_{2}$ Secara Bersama-Sama dengan $Y$

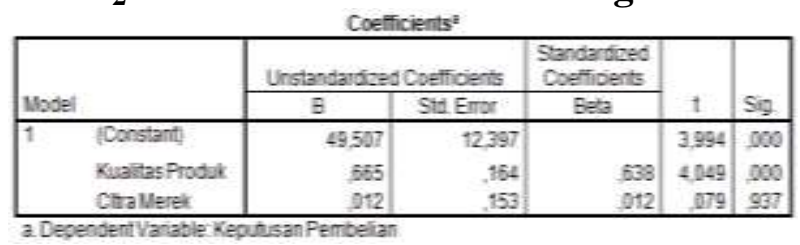

Persamaan regresi berganda yaitu $\hat{Y}=49,507+0,665 X_{1}+0,012 X_{2}$. Persamaan fungsional berganda ini dapat diartikan bahwa nilai konstanta (a) sebesar 49,507 berarti bahwa jika nilai kualitas produk $\left(\mathrm{X}_{1}\right)$ dan citra merek $\left(\mathrm{X}_{2}\right)$ konstan atau 0, maka keputusan pembelian sebesar 49,507. Nilai $b_{1}$ dalam persamaan garis fungsional berganda $\mathrm{Y}=\mathrm{a}+\mathrm{b}_{1} \mathrm{X}_{1}+\mathrm{b}_{2} \mathrm{X}_{2}$ jadi $\mathrm{b}_{1}=0,665$ artinya setiap peningkatan satu satuan dari kualitas produk $\left(\mathrm{X}_{1}\right)$ berarti akan mempengaruhi peningkatan keputusan pembelian sebesar 0,665 satuan dengan syarat citra merek $\left(\mathrm{X}_{2}\right)$ konstan. Nilai $b_{2}$ dalam persamaan garis fungsional berganda $Y=a+b_{1} X_{1}+b_{2} X_{2}$ jadi $b_{2}=0,012$ artinya setiap peningkatan satu satuan dari citra merek $\left(\mathrm{X}_{2}\right)$ berarti akan mempengaruhi peningkatan keputusan pembelian sebesar 0,012 satuan dengan syarat variabel kualitas produk $\left(\mathrm{X}_{1}\right)$ konstan.

\section{Analisis Dimensi variabel Kualitas Produk $\left(\mathbf{X}_{1}\right)$ dan Citra merek $\left(\mathbf{X}_{2}\right)$ dengan Keputusan Pembelian (Y)}

Untuk mengetahui hubungan korelasional variabel bebas dan indikatornya dengan variabel terikat dan indikatornya maka dilakukan uji analisis dimensi. Perhitungan menggunakan SPSS 20 tentang koefisien korelasi indikator variabel kualitas produk $\left(\mathrm{X}_{1}\right)$ dan citra merek $\left(\mathrm{X}_{2}\right)$ dengan keputusan pembelian (Y) dapat dilihat pada tabel berikut:

Tabel 10. Koefisien Korelasi antara Indikator Kualitas Produk $\left(\mathrm{X}_{1}\right)$ dan Citra Merek $\left(\mathrm{X}_{2}\right)$ Dengan Keputusan Pembelian (Y)

\begin{tabular}{|c|c|c|c|c|c|c|c|c|}
\hline \multirow[b]{2}{*}{ Variabel } & \multirow[b]{2}{*}{ Indikater } & \multicolumn{7}{|c|}{$\varepsilon_{3 x}$} \\
\hline & & $\mathrm{y}_{\mathrm{t}}$ & $\mathrm{y}_{2}$ & $\mathrm{y}_{3}$ & $\mathrm{y}_{4}$ & $\mathrm{y}_{5}$ & $\mathrm{y}_{6}$ & $\mathrm{y}_{7}$ \\
\hline \multirow{8}{*}{$\mathrm{X}_{\mathrm{L}}$} & $\mathbf{x}_{1.1}$ & 0,509 & 0,573 & 0,480 & 0,570 & 0,339 & 0,530 & 0,422 \\
\hline & $x_{1 \cdot 2}$ & 0,630 & 0,610 & 0,718 & 0,744 & 0,405 & 0,672 & 0,612 \\
\hline & $x_{1.3}$ & 0,551 & 0,788 & 0,768 & 0,595 & 0,593 & 0,523 & 0,519 \\
\hline & $x_{1.4}$ & 0,755 & 0,403 & 0,747 & 0,825 & 0,243 & 0,823 & 0,800 \\
\hline & $x_{t .5}$ & 0,789 & 0,372 & 0,690 & 0,816 & 0,144 & 0,869 & 0,796 \\
\hline & $x_{1.6}$ & 0,679 & 0,529 & 0,764 & 0,734 & 0,321 & 0,762 & 0,735 \\
\hline & $x_{1 \cdot 7}$ & 0,742 & 0,398 & 0,658 & 0,877 & 0,145 & 0,843 & 0,809 \\
\hline & $x_{1.8}$ & 0,689 & 0,602 & 0,761 & 0,756 & 0,364 & 0,806 & 0,820 \\
\hline \multirow{5}{*}{$\mathrm{X}_{2}$} & $x_{2 \cdot 1}$ & 0,611 & 0,234 & 0,695 & 0,777 & 0,135 & 0,875 & 0,875 \\
\hline & $\mathrm{x}_{2.2}$ & 0,705 & 0,348 & 0,695 & 0,676 & 0,236 & 0,722 & 0,732 \\
\hline & $x_{2.3}$ & 0,759 & 0,248 & 0,753 & 0,741 & 0,247 & 0,789 & 0,830 \\
\hline & $\mathrm{x}_{2.4}$ & 0,804 & 0,392 & 0,748 & 0,848 & 0,179 & 0,822 & 0,861 \\
\hline & $\mathrm{X}_{2.5}$ & 0,606 & 0,344 & 0,773 & 0,793 & 0,221 & 0,793 & 0,914 \\
\hline
\end{tabular}


Hasil Analisis dimensi dapat diketahui hubungan antara dimensi variabel bebas dengan dimensi variabel terikat adalah :

\section{Variabel Kualitas Produk}

a) Dimensi yang paling tinggi nilainya adalah dimensi "Keindahan (estetika)" $\left(\mathrm{X}_{1.7}\right)$ yang memiliki hubungan paling kuat dengan dimensi "Melakukan pembelian ulang" $\left(\mathrm{Y}_{4}\right)$ pada variabel keputusan pembelian dengan koefisien korelasi 0,877 (hubungan sangat kuat). Sehingga dapat dikatakan bahwa dimensi kualitas produk yang paling menentukan keputusan pembelian yaitu dimensi keindahan (estetika). Hal ini dikarenakan konsumen merasa gengsi atau status sosialnya meningkat jika membeli atau mengendarai mobil Hyundai. Hal ini menjadikan keputusan pembelian lebih sering terjadi (repeat order) dari pelanggan yang sudah memiliki atau membeli mobil Hyundai sebelumnya. Sehingga unsur keindahan (estetika) menjadi faktor dominan keputusan pembelian.

b) Dimensi yang paling rendah hubungannya adalah dimensi "Daya Tahan (durability)" $\left(\mathrm{X}_{1.5}\right)$ dengan dimensi "Pembelian Sendiri" $\left(\mathrm{Y}_{5}\right)$ dengan koefisien korelasi 0,144 (hubungan sangat lemah). Hal ini dapat terjadi karena masih banyaknya pelanggan yang belum yakin akan kualitas/daya tahan (durability) mobil Hyundai terutama daya tahan mesinnya. Sehingga menyebabkan lemahnya pelanggan untuk memutuskan pembelian mobil Hyundai.

\section{Variabel Citra Merek}

a) Pada variabel citra merek dimensi yang paling kuat hubungannya adalah dimensi "loyalty" (kesetiaan) $\left(\mathrm{X}_{2.5}\right)$ yang memiliki hubungan paling kuat dengan dimensi "Bertindak karena keunggulan produk" $\left(\mathrm{Y}_{7}\right)$ pada variabel keputusan pembelian dengan koefisien korelasi 0,914 (hubungan sangat kuat).
Dengan demikian dapat dikatakan bahwa pada dimensi citra merek yang paling menentukan keputusan pembelian adalah komponen loyalty atau kesetiaan. Hal ini dikarenakan pelanggan sudah sangat puas dan yakin akan produk (mobil Hyundai) yang di belinya.

b) Dimensi yang paling rendah adalah dimensi "corporate image" (citra perusahaan) $\left(\mathrm{X}_{2.1}\right)$ dengan dimensi "Pembelian Sendiri" ( $\left.\mathrm{Y}_{5}\right)$ dengan koefisien korelasi 0.135 (hubungan sangat lemah). Hal ini dapat terjadi karena "corporate image" (citra perusahaan) masih lemah di benak pelanggan dan image sebagai mobil rakitan Korea masih diasumsikan oleh pelanggan rentan atau mudah rusak serta harga jual yang merugi.

\section{Keterbatasan Penelitian}

1. Penelitian ini dibatasi pada dua variabel bebas yaitu variabel kualitas produk $\left(\mathrm{X}_{1}\right)$ dan citra merek $\left(\mathrm{X}_{2}\right)$ yang mempunyai hubungan dengan keputusan pembelian (Y) sehingga penarikan kesimpulan atas temuan tentang keputusan pembelian terbatasi pada variabel tersebut, sementara itu masih banyak variabel-variabel lainnya yang memiliki hubungan dengan keputusan pembelian seperti promosi, harga, lokasi dan variabel-variabel lainnya. Oleh karena itu diperlukan penelitian lebih lanjut dengan menggunakan variabelveriabel lain yang berhubungan dengan keputusan pembelian.

2. Populasi penelitian ini dibatasi hanya mencakup pelanggan mobil Hyundai di wilayah Serpong, Tangerang. Dengan demikian, hasil penelitian terbatas digeneralisasi pada populasi pelanggan mobil Hyundai di wilayah Kota Tangerang. Hasil penelitian ini akan menjadi lebih luas jika populasi juga 
diperluas, misalnya pelanggan mobil Hyundai di wilayah Jabodetabek.

3. Sampel penelitian sangat terbatas, yaitu berjumlah 87 responden dari 110 populasi dan dibatasi dengan taraf signifikansi sebesar $\alpha=0,05$, sehingga bila sampel lebih banyak maka hasil dari riset ini akan lebih akurat dengan taraf signifikansi $\alpha=$ 0,01

4. Penelitian ini mempunyai keterbatasan variabel dan keterbatasan lingkup populasi, oleh sebab itu penelitian ini hanya dapat memprediksi perilakuperilaku keputusan pembelian pelanggan mobil Hyundai di wilayah Serpong, Tangerang.

\section{SIMPULAN DAN IMPLIKASI}

Berdasarkan hasil pengumpulan data melalui kuesioner yang disebarkan kepada 87 responden dan telah dianalisis, maka ada beberapa hasil yang dapat disimpulkan yaitu:

1. Terdapat hubungan positif kualitas produk dengan keputusan pembelian sehingga didapat persamaan $\hat{\mathrm{Y}}=49,605+0,676 \mathrm{X}_{1}$, dengan koefisien korelasi $(\mathrm{r})=0,649$ artinya terdapat hubungan yang kuat antara kualitas produk dengan keputusan pembelian dengan kontibusinya sebesar $42,1 \%$. Dengan demikian, keputusan pembelian dapat ditingkatkan melalui peningkatan kualitas produk.

2. Terdapat hubungan positif antara citra merek dengan keputusan pembelian dengan persamaan $\hat{\mathrm{Y}}=71,325+0,540 \mathrm{X}_{2}$ dengan koefisien korelasi $(\mathrm{r})=0,555$ artinya,terdapat hubungan kategori sedang antara citra merek dengan keputusan pembelian dengan kontibusinya sebesar $30,8 \%$.

3. Terdapat hubungan positif antara kualitas produk $\left(\mathrm{X}_{1}\right)$ dan citra merek $\left(\left(\mathrm{X}_{2}\right)\right.$ secara bersama-sama dengan keputusan pembelian dengan persamaan $\hat{\mathrm{Y}}=49,507+$ $0,665 X_{1}+0,012 X_{2}$, dengan koefisien korelasi $(\mathrm{r})=0,649$ artinya terdapat hubungan yang kuat antara kualitas produk dan citra merek secara bersama-sama dengan keputusan pembelian dengan kontibusinya sebesar 42,1 \%. Dengan demikian keputusan pembelian dapat ditingkatkan melalui peningkatan kualitas produk dan citra merek secara bersamasama.

\section{Implikasi}

Berdasarkan kesimpulan diatas maka sebagai upaya untuk meningkatkan keputusan pembelian maka implikasi yang dapat disampaikan adalah:

1. Upaya peningkatan keputusan pembelian melalui kualitas produk dilakukan dengan cara :

a. Mempertahankan dan meningkatkan mutu estetika atau keindahan dari eksterior dan interior mobil Hyundai sehingga pelanggan menjadi setia (loyal) dan membeli kembali mobil tersebut.

b. Meningkatkan perbaikan unsur-unsur kualitas produk secara keseluruhan terutama yang memiliki hubungan sangat lemah dengan keputusan pembelian yaitu daya tahan (durability) melalui edukasi pada konsumen.

2. Upaya peningkatan keputusan pembelian melalui citra merek dapat dilakukan dengan cara, yaitu :

a. Mempertahankan dan meningkatkan perhatian pada unsur-unsur citra merek secara menyeluruh terutama yang memiliki hubungan sangat kuat dengan keputusan pembelian yaitu "Loyalitas" dan "Bertindak karena keunggulan produk", yang artinya bahwa jika citra merek atau image kualitas produk menjadi lebih baik maka akan meningkatkan loyalitas pelanggan dan akan meningkatkan prioritas dari konsumen atau pelanggan untuk membeli mobil Hyundai. 
b. Meningkatkan perbaikan unsurunsur citra merek secara keseluruhan terutama yang memiliki hubungan sangat lemah dengan keputusan pembelian yaitu "corporate image" yaitu melalui edukasi terhadap konsumen dan promosi

3. Upaya peningkatan keputusan pembelian melalui kualitas produk dan citra merek secara bersama-sama adalah manajemen PT.Hyundai dapat melakukan evaluasi secara berkala tentang kualitas produk yang dilakukan secara bersama-sama dengan citra merek terhadap keputusan pembelian melalui riset sederhana.

\section{UCAPAN TERIMA KASIH}

Ucapan terima kasih kepada Manajemen PT. Hyundai Mobil Indonesia cabang -Serpong-Tangerang.

\section{DAFTAR PUSTAKA}

Aaker, David A. 2010. Manajemen Ekuitas Merek. Jakarta. Mitra Utama

,Biel, L. 2009. Loyalitas Merek dan Periklanan, Alih bahasa oleh Aris Ananda. Jakarta. Mitra Utama.

Buchari Alma. 2014. Manajemen Pemasaran dan Pemasaran Jasa. Bandung. Alfabeta.

Cannon, Joseph P.,William D.Perreault Jr , Jerome Mc.Carthy. 2008. Pemasaran Dasar-Dasar. Pendekatan Managerial Global. Edisi 16. Jilid 2. Alih bahasa Diana Angelica dan Ria Cahyani. Jakarta. Salemba Empat.

Danang Sunyoto. 2015. Perilaku Konsumen dan Pemasaran. Jakarta. Center For Academic Publishing Service (CAPS).

Etta Mamang Sangadji \& Sopiah. 2013. Perilaku Konsumen. Yogyakarta. CV. Andi Offset.
Fandy Tjiptono. 2008. Strategi Pemasaran. Edisi II. Yogyakarta. Penerbit Andi . 2007. Pemasaran Jasa. Yogyakarta. Banyumedia Publishing.

Farida Jasfar. 2009. Manajemen Jasa. Bogor. Ghalia Indonesia

Hamel, Gary \& CK Prahalad. 2000. Competing of The Future Cambridge American National Standar

Harman, Malau. 2017. Manajemen Pemasaran. Bandung. Alfabeta.

Hoeffer, Steve,Keller,Kevin Lane. 2003. The Marketing Advantage of Strong Brands. Brand Management, Vol. 10, No.6.

Husaini Usman, \& Purnomo Setiady Akbar. 2011. Pengantar Statistik. Edisi Kedua. Jakarta. PT.Bumi Aksara

Hermawan Kertajaya. 2004. Hermawan Kertajaya on Marketing. Jakarta. PT. Gramedia Pustaka Utama.

Kotler,P.1995. Manajemen Pemasaran. Jakarta. PT. Indeks Kelompok Gramedia. 2005. Manajemen Pemasaran, Jilid 1 dan 2. Jakarta. PT. Indeks Kelompok Gramedia.

Kotler, Phillip \& Keller, Kevin Lane. 2013. Manajemen Pemasaran. Edisi 13 Jilid 1, Alih bahasa Bon Sabran. Jakarta. Erlangga . . 2009. Manajemen Pemasaran. Edisi 13 jilid 1, Alih bahasa Bob Sabran. Jakarta : Erlangga. 2002. Manajemen Pemasaran. Edisi Millenium. Jilid 1. Jakarta. Prenhallindo.

2001. Manajemen Pemasaran. Edisi 7. Jilid 1. Alih bahasa Benyamin Molan. Jakarta : Erlangga. \& Armstrong, Garry. 2008, Prinsip-Prinsip Pemasaran. Jilid 1, Edisi 12 . Jakarta. Erlangga. .2003. Dasar-Dasar Pemasaran. Alih Bahasa. Edisi 9. Jakarta. PT. Indeks. 
Low, George S, Lamb Jr, Charles W. 2000. The Measurement and Dimensionality of Brand Assosiations, Journal of Product and Brand Management. Vol. 9 No.6.

Mohamad Syamsul, \& Ma'arif Hendri Tanjung. 2003. Manajemen Operasi. Jakarta. PT. Grasindo.

Nasution. 2005. Manajemen Mutu Terpadu. Bogor. Ghalia Indonesia.

Nugroho J. Setiadi.2013. Perilaku Konsumen. Edisi Revisi. Jakarta. Kencana Prenada Media Grup.

Rambat Lupiyoadi. 2013. Manajemen Pemasaran Jasa. Jakarta. Salemba Empat.

Riduwan \& Sunarto. 2011. Pengantar Statistik. Alfabeta. Bandung.

Schiffman, Kanuk. 2002. Perilaku Konsumen, Edisi 3. Jakarta. Macaman Jaya Cemerlang. .2007. Perilaku Konsumen, Edisi 7. Jakarta. Macaman Jaya Cemerlang

Sunarto. 2004. Pengantar Manajemen Pemasaran. Yogyakarta. UST Press

Sugiono.2010. Metode Penelitian Bisnis. Bandung. Alfabeta.

Supardi U.S. 2013. Aplikasi Statistika Dalam Penelitian. Jakarta. Change Publication.

Sutisna. 2003. Perilaku Konsumen dan Komunikasi Pemasaran. Bandung. PT. Remaja Rosdakarya.

Tatik Suryani. 2008. Perilaku Konsumen:Implikasi Pada Strategi Pemasaran. Edisi 1. Yogyakarta. Graha Ilmu.

Thamrin Abdullah \& Francis Tantri. 2012. Manajemen Pemasaran. Jakarta. Raja Grafindo Persada

Tony Wijaya. 2011. Manajemen Kualitas Jasa. Jakarta. PT. INDEKS.

Zulian Yamit. 2013. Manajemen Kualitas Produk Dan Jasa, Cetakan keenam.Yogyakarta : Ekonosia.
GAIKINDO]. Gabungan Industri Kendaraan Bermotor Indonesia. 2016. Tingkat Penjualan Mobil Nasional [Internet]. Diakses pada 18 April 2017 Tersedia pada:http://www.gaikindo.com.

Akbar, A. 2012. Analisis Pengaruh Citra Merek, Harga, Kualitas Produk, Terhadap Keputusan Pembelian Notebook Toshiba, Fakultas Ekonomi Jurusan Manajemen Universitas Gunadarma, Jakarta. Diakses pada tanggal 20 April 2017.

Bagaskara, AM (2014). Pengaruh Kualitas produk, Harga dan Citra Merek terhadap Keputusan pembelian Sepeda Motor Honda Vario di Semarang. Skripsi.Universitas Diponegoro Semarang. http://eprint.undip.ac.id/42886/1/BAG ASKARA.pdf. Diakses pada tanggal 20 April 2017

Fauziah Ramadhani (2015). Pengaruh Kualitas, Harga dan Citra Merek terhadap Keputusan Pembelian Mobil LCGC Toyota Agya di Wilayah Jabodetabek.http://repository.ipb.ac.id/ bitstream/handle/123456789/76788/H1 5fra.pdf?sequence $=1$. Diakses tanggal 20 April 2017.

Mohammad Tambrin (2010). Pengaruh Brand Image terhadap Pelanggan Kartu Simpati Terhadap kepuasan Mahasiswa Univesitas Trunijoyo, Jurnal Studi Manajemen. Vol 4 No.1. Diakses pada tanggal 20 April 2017.

Ria Maharani Ridhwan ,2014. Pengaruh Citra Merek dan Kualitas Produk terhadap Keputusan Pembelian Mobil Honda All New Jazz di Kota Malang. Jurnal, Manajemen Fakultas Ekonomi dan Bisnis, Universitas Brawijaya, Malang.http://jimfeb.ub.ac.id/index.ph p/jimfeb/article/download/1051/965 Diakses tanggal 20 April 2017. 